\title{
TEXTURAL AND MINERALOGICAL VARIATIONS IN THE SURFICIAL SEDIMENTS OF CHAGVAN BAY, ALASKA: SOME STRATIGRAPHIC IMPLICATIONS OF A SUBARCTIC BAY*
}

\section{ROBERT M. OWEN and J. ROBERT MOORE}

Department of Atmospheric and Oceanic Science, The University of Michigan, Ann Arbor, Mich. 48109 (U.S.A.)

Institute of Marine Science, University of Alaska, Fairbanks, Alaska 99701 (U.S.A.)

(Received August 18, 1977)

\begin{abstract}
Owen, R.M. and Moore, J.R., 1978. Textural and mineralogical variations in the surficial sediments of Chagvan Bay, Alaska: some stratigraphic implications of a subarctic bay. Mar. Geol., 28: 145-161.

The surficial sediments of Chagvan Bay consist of: (1) coarse-grained ( $-3 \phi$ to $-2 \phi)$ lithic fragments of dunites, diorites and sandstones; $(2)$ fine sands $(2-3 \phi)$ composed of quartz and feldspar; and (3) coarse silts $(4-5 \phi)$ composed mostly of quartz. The lithic fragments primarily result from wave erosion of the coastal bluffs, while the fine sands are transported into the bay by tidal currents and the coarse silts by fluvial currents. During successive ebb tides tidal currents remove most or all of the newly deposited material and tend to maintain a balance between erosion and deposition.

The texture and mineralogy of the bay deposits are primarily controlled by provenance. Inasmuch as most of the sedimentary particles are being supplied at present and the dispersal of the surficial sediments reflects the present configuration of distributor processes, the sediments are classified as "neoteric".

Benthic epifauna are present only in relatively low-energy depositional areas, although other parts of the bay offer a similar environment. For this reason, it is postulated that the distribution of benthic organisms is influenced by the scouring activity of currents.

Although there is seasonal ice-cover, the sediments rapidly acquire characteristics which reflect the energy regime during the ice-free period and form a hydraulically graded profile. It is concluded from this that the sediments are always at or near an equilibrium state, and that this situation should lead to a diastem or unconformity in the stratigraphic record.
\end{abstract}

\section{INTRODUCTION}

The study of modern marine sediments is concerned with providing detailed characterizations of such sediments and their relationships to each other and

\footnotetext{
*Contribution No. 242 from the Department of Atmospheric and Oceanic Science, University of Michigan, Ann Arbor.
} 
to the depositional regime. This information is applicable to the traditional scientific objectives of discovering criteria for interpreting ancient deposits and reconstructing paleoenvironments, and is often pertinent to immediate practical requirements, such as augmenting mineral exploration programs and providing environmental baseline data. All of these considerations have led to an intensification in the study of modern marine deposits during the last decade (Ferentinos, 1976). However, large gaps still remain in our knowledge of certain regions. One geographic region which has received little attention is the southwestern coast of Alaska. The several Holocene bays which indent this coastline, such as Chagvan Bay, are essentially virgin territories for scientific investigation. Moreover, Chagvan Bay and other bays along this coastline contain either known or suspected placer-like accumulations of noble metals in the surficial sediments (Moore, 1972; Moore and Welkie, 1976; Owen and Moore, 1976). The objectives of this study were to determine the textural and mineralogical characteristics of the surficial sediments of Chagvan Bay, to relate this information to the depositional processes and to consider the stratigraphic implications of these deposits.

\section{PHYSICAL SETTING}

\section{Relief and regional geology}

Chagvan Bay (Fig.1) is located in the southwestern corner of Alaska and forms part of the southeastern coast of the Bering Sea. Local relief includes several abrupt peaks and deep valleys which are primarily the result of Quaternary glaciation. Except for a tidal channel, about $500 \mathrm{~m}$ in width, the western boundary of the bay is separated from the Bering Sea by a narrow spit (Fig.2). Coastal bluffs, consisting of unconsolidated glacial debris and outwash deposits, form the northern, eastern and most of the southern boundaries of the bay. Cliffs of weathered bedrock form the remainder of the southern shoreline. Fluvial input into Chagvan Bay is mainly from the Kinegnak River. Other stream channels which drain into the bay are active only when transporting meltwater from the surrounding mountains.

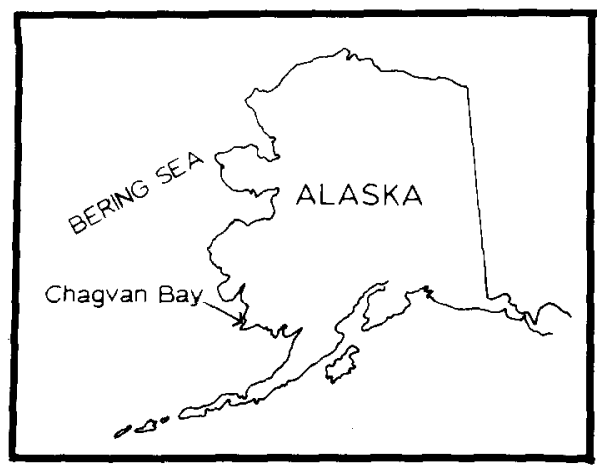

Fig.1. Map showing location of Chagvan Bay in relation to the Bering Sea Coast of Alaska. 


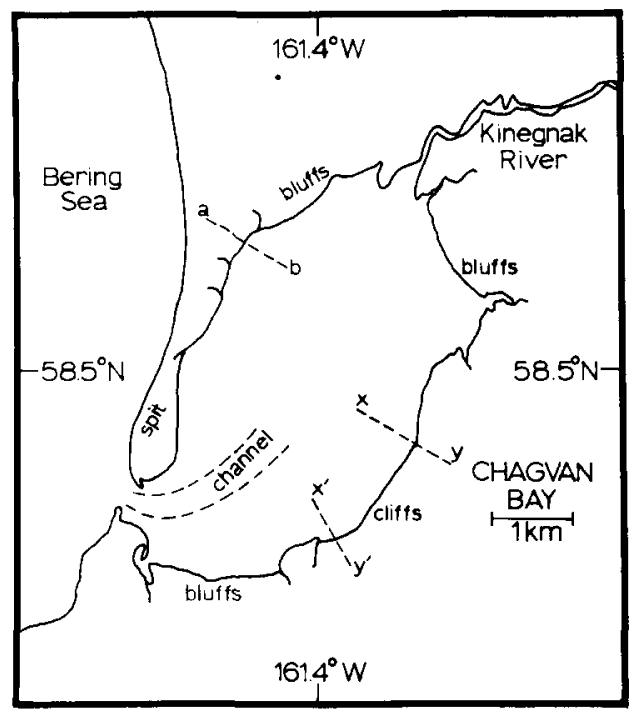

Fig.2. Chagvan Bay and the surrounding area. Line $a b$ is the approximate boundary between the spit deposits and the older bluff deposits. Lines $x y$ and $x^{\prime} y^{\prime}$ are the approximate boundaries between the bedrock cliffs and the bluff deposits along the southeastern coastline.

Outcrops in the study area range in age from Late Paleozoic to Tertiary (Mertie, 1940). These are chiefly massive, altered volcanic rocks, black and greenish-black serpentinized dunite and peridotite, massive to thin-bedded siliceous sandstone and chert, with lesser amounts of calcareous siltstone, fine-grained graywacke and limestone (Hoare and Coonrad, 1961). The bedrock is generally covered with unconsolidated preglacial sediments composed of deeply weathered gravel, sand, silt and clay. These deposits are, in turn, covered with a layer of glacial drift which reflects four distinct periods of glaciation: the uppermost level of glacial drift has been dated at $8910 \pm 110 \mathrm{yr}$ B.P. (Porter, 1967). The surface layer of sediment is approximately $60 \mathrm{~m}$ thick and consists of unconsolidated postglacial outwash deposits covered with a mat of tundra vegetation.

Noble metal placers, particularly platinum, have been mined in the lower Salmon River Valley, about $20 \mathrm{~km}$ north of Chagvan Bay, since 1934. The platinum occurs mainly on the surface and in the crevices of bedrock, but is also present in the lower $1 \mathrm{~m}$ of the overlying gravel (Mertie, 1976). The mining history and general and economic geology of this region have been extensively reported by Mertie $(1940 ; 1969 ; 1976)$. Small zones of platinum enrichment $(0.03-0.5 \mathrm{ppm})$ above baseline levels $(<0.01 \mathrm{ppm})$ also occur in the modern sediments of Chagvan Bay (Owen and Moore, 1976) and in the nearshore surficial sediments of the Bering Sea adjacent to the bay (Moore and Welkie, 1976). The spatial extent and value of platinum in these modern deposits has yet to be determined. 


\section{Hydrography}

Chagvan Bay is a shallow tidal estuary. No comprehensive hydrological data are available, although a series of current velocity and tidal range measurements made during the summers of 1973 and 1974 do delineate the gross hydrological features (Owen, 1975). These measurements indicate that, at least during the summer months, a predominantly southward-flowing littoral current (1-2 $\left.\mathrm{m} \mathrm{sec}^{-1}\right)$ occurs along the Bering Sea coast. A general southward flow is also suggested by the well-developed spit at the entrance to the bay. Within the bay, the tidal channel extends northeast approximately one-third of the distance along the principal axis. Tidal current speeds are relatively strong in the bay mouth $\left(2-3 \mathrm{~m} \mathrm{sec}^{-1}\right)$ and considerably diminished in the bay proper $\left(0.5-1.0 \mathrm{~m} \mathrm{sec}^{-1}\right)$. The path described by the tidal current within the bay forms a counterclockwise gyre which remains close to the southern shore before bending north in the upper reaches and finally turning southwest and flowing parallel to the northern coast. This counterclockwise pattern is typical of semienclosed basins in northern high latitudes (von Arx, 1967).

The tides are mixed-semidiurnal and the maximum tidal range at the bay mouth is about $2.5 \mathrm{~m}$. The mean water depth in the bay is about $2 \mathrm{~m}$ at mean high tide. Except for the tidal channel, the bay is almost entirely drained at low tide. Observations of the flow from the Kinegnak River at low tide show that it follows a relatively straight path which extends from the mouth of the river and joins the tidal channel. The current in the Kinegnak River was measured at $0.5-1.0 \mathrm{~m} \mathrm{sec}^{-1}$ in July of 1974 ; however, it is probable that current speeds are considerably higher than this when the flow is augmented by snowmelt earlier in the spring. Average summer wave heights along the Bering Sea coast and within Chagvan Bay are $2 \mathrm{~m}$ and $1 \mathrm{~m}$, respectively. The coastal bluffs surrounding the bay are being actively eroded by wave action.

\section{METHODS OF STUDY}

Surficial sediment samples (Fig.3) were collected using a pipe dredge $0.5 \mathrm{~m}$ long with a cross-sectional area of about $250 \mathrm{~cm}^{2}$. The pipe dredge was lowered over the stern of a 5-m boat, while drifting, allowed to penetrate the sediments and was immediately recovered. The average penetration depth was $10 \mathrm{~cm}$ and the average sample size was about $2 \mathrm{~kg}$. Because of the small size of the boat and the relatively shallow depths of water, this method of obtaining grab samples was found to be more convenient than conventional grabsampling techniques. Sample stations were located through triangulation with physiographic highs serving as fixed navigation points.

Prior to analysis each sample was air-dried in a dust-free environment. Clumps of sediment which formed during the drying process were lightly disaggregated with a rubber stopper. A sample splitter was used to obtain similar subsamples for each type of analysis. The textural analysis was according to the methods described by Folk (1974). The samples were sieved at $0.5 \phi$ 


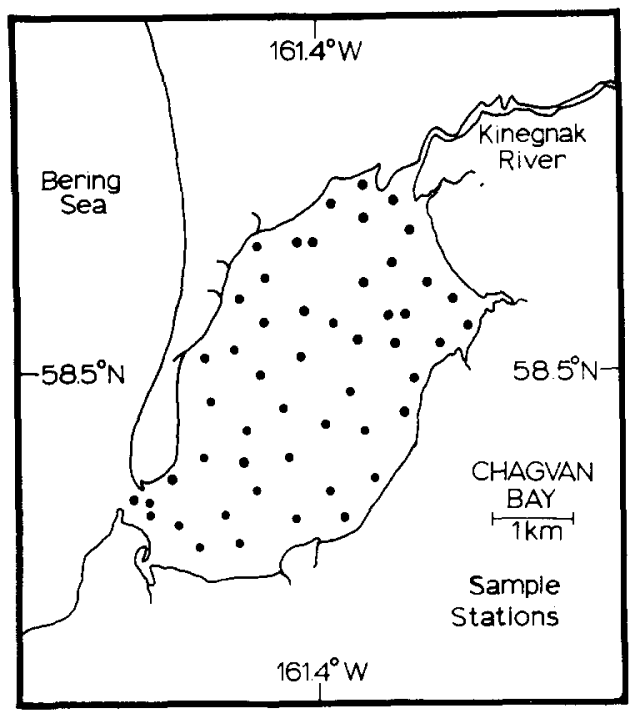

Fig.3. Location of samples analyzed in this study. Samples were collected with a pipe dredge which had an average penetration depth of $10 \mathrm{~cm}$.

intervals and thereby divided into the various grain size classes (Wentworth, 1922) ranging from -3.5 to $4.5 \phi$. A pipette analysis of samples which had a fraction finer than $4.5 \phi$ showed that this fraction did not contain more than $1.5 \%$ of material finer than $5.0 \phi$. Moment statistics of the size frequency distribution were calculated using the computer program described by Coakley and Beal (1972), which was modified slightly to be compatible with the University of Wisconsin computer system.

Standard petrographic techniques were used to identify mineral grains of all sizes in thin sections, and at least 200 grains in each sample were counted. The various minerals were grouped into seven compositional classes:

(1) yuartz-feldspar, (2) micas, (3) amphiboles, (4) pyroxenes, (5) lithic fragments, (6) opaques and (7) "others" (all other minerals).

Grain roundness analyses of quartz and feldspar grains were done according to the visual comparison method developed by Powers (1953).

\section{RESULTS}

A complete tabulation of data for individual samples is given in Owen (1975). The results of the various analyses are summarized here in contour charts and classification diagrams.

\section{Sediment texture}

The sediments of Chagvan Bay range from black, coarse silts to clean, washed gravels and boulders. Shell fragments of Mytilus edulis and Cryptoma 
californica and live organisms of the latter were present in several samples taken from the quiescent zone behind the north spit. In general, however, there is a notable lack of benthic epifauna associated with the bay deposits.

Visual inspection of grain-size histograms (not shown) indicates $19 \%$ of the samples are unimodal, $64 \%$ are bimodal and the remainder are trimodal. The gravel $(-3$ to $-2 \phi)$, fine sand $(2-3 \phi)$ and coarse silt ( $4-5 \phi)$ size classes contain major modes at about $-2.7,2.5$ and $4.5 \phi$, respectively. Five distinct sediment textural facies are present: gravels, sandy gravels, sands, silty sands and gravelly silts (Fig.4). The nearshore depositional areas are generally composed of sandy gravels except at the mouth of the bay, near the outlet of the Kinegnak River and along the shoreline in the upper half of the bay. Sandy gravels also occur in the tidal channel and grade into sands in the central portions of the bay. Gravelly silts are present at the mouth of the Kinegnak River, and from here they form two tongues of sediment which run parallel to the eastern and western shoreline, respectively. Each of these tongues is separated from the shoreline by a zone of sandy gravels and both grade into silty sands in the middle of the bay. The distribution of unimodal facies is limited: gravels occur only on either side of the bay mouth and sands are primarily limited to an elongate patch in the southwestern portion of the bay.

Contour charts of the mean grain size and sorting values are shown in Figs.5 and 6, respectively. The information that can be inferred from these parameters is somewhat limited because of the high degree of multimodality of the sediments. Multimodal sediments generally consist of different subpopulations and the grain-size distributions of these subpopulations are often superimposed (Spencer, 1963). For this reason, the grain-size statistical parameters of multimodal sediments tend to vary in a complex manner with the

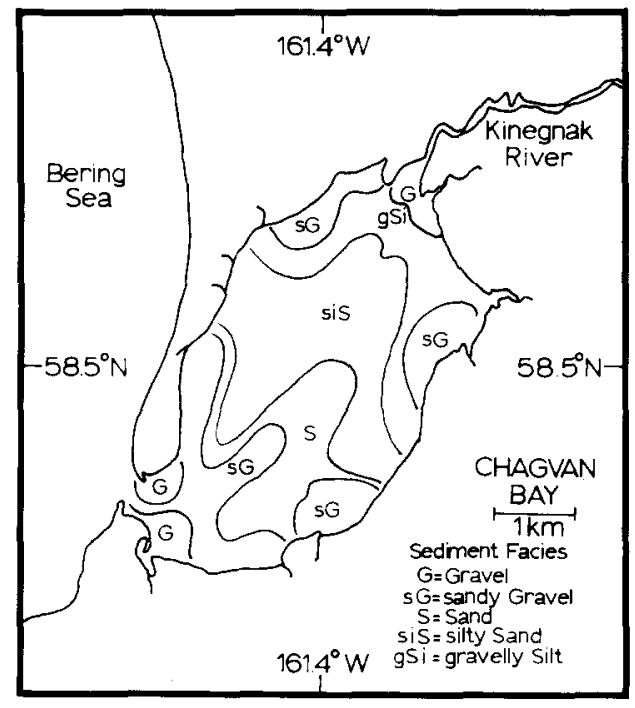

Fig.4. Distribution of five major facies present in Chagvan Bay sediments. Sediments are classified according to the Folk (1974) classification scheme. 

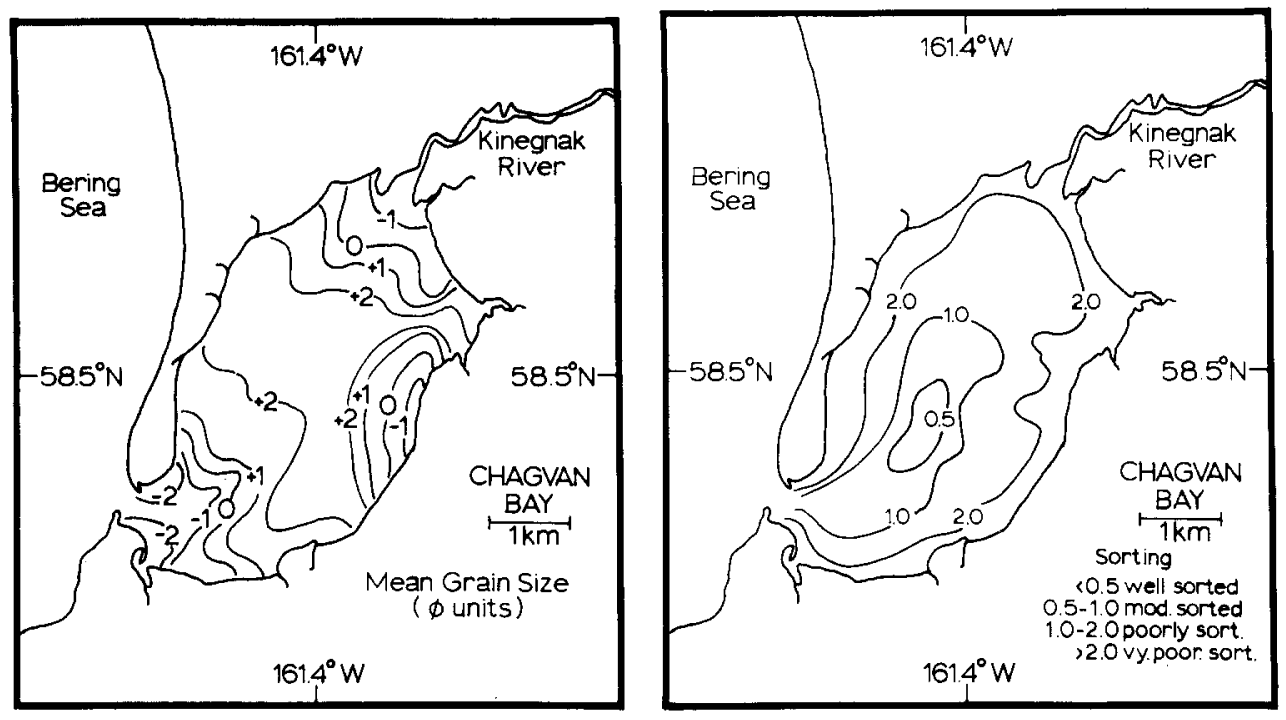

Fig.5. Mean grain size of surficial sediments, showing gradation from coarse to fine sediments along observed current directions; i.e., from bay mouth to head of tidal channel and from outlet of Kinegnak River toward bay mouth along northeastern coastline (see also Fig.6).

Fig.6. Sorting of bay sediments, showing gradation from very poorly sorted to moderately to poorly sorted sediments, extending from nearshore areas to the central portions of the bay; well-sorted sediments occur only at the head of the tidal channel (see also Fig.5).

size and proportion of the modes present (Slatt, 1975). Although the high degree of multimodality limits the interpretive value of the mean and sorting parameters, an examination of Figs.5 and 6 is nevertheless instructive. For example, the mean grain size displays an obvious gradation from coarse to fine sediments extending away from the coast. This trend is particularly well defined in two locations where it runs parallel to observed current directions: (1) along the main axis of the bay from the bay mouth to the head of the tidal channel; and (2) from the outlet of the Kinegnak River toward the bay mouth along the northwestern coast. Furthermore, using the descriptive nomenclature suggested by Folk (1974), it is observed that moderately sorted and well-sorted deposits occur only in the tidal channel, while nearshore sediments are very poorly sorted and grade into moderately to poorly sorted sediments in the middle of the bay. Thus, both the mean and sorting parameters indicate that the sediment surface represents a hydraulically graded profile (Booth and Gorsline, 1974), and the significance of this with respect to depositional energy levels in the bay will be discussed in a subsequent section. 


\section{Sediment mineralogy}

Mineral grains in thin sections were identified to establish a framework for the compositional classification of the sediments, to relate bay sediments to source areas and to provide corroborative data in support of interpretations drawn from the textural analyses. Quartz-feldspar and lithic fragments are the predominant mineralogical groups and together account for more than $75 \%$ of the grains identified in most samples. Minerals in the pyroxene group $(0-11 \%)$ are primarily augite, diopside, enstatite and hypersthene. Biotite, muscovite and, to a lesser extent, chlorite are the main constituents of the mica group (0-15\%). Hornblende is the major component of the amphibole group $(0-8 \%)$, and the opaque minerals $(0-10 \%)$ are primarily magnetite and chromite.

A compositional classification (van Andel, 1958) established that the sediments are the clastic equivalents of graywackes or subgraywackes, with a few assigned to the subarkose category (Fig.7). The lithic fragments have a broad compositional range: sandstone, diorite and dunite fragments are most common, while lesser amounts of siltstones, conglomerates and tuffs are also present. The dunites, characterized by greenish-black olivine crystals, often show alteration to serpentine, undulatory streaks of pyroxene and thin veinlets of opaque minerals. Plagioclase is dominant within the feldspars, although some orthoclase and perthite grains are usually present.

\section{Grain roundness}

The majority (96\%) of the samples were classified as subangular and the remainder as subrounded. However, the subrounded class is contiguous to the

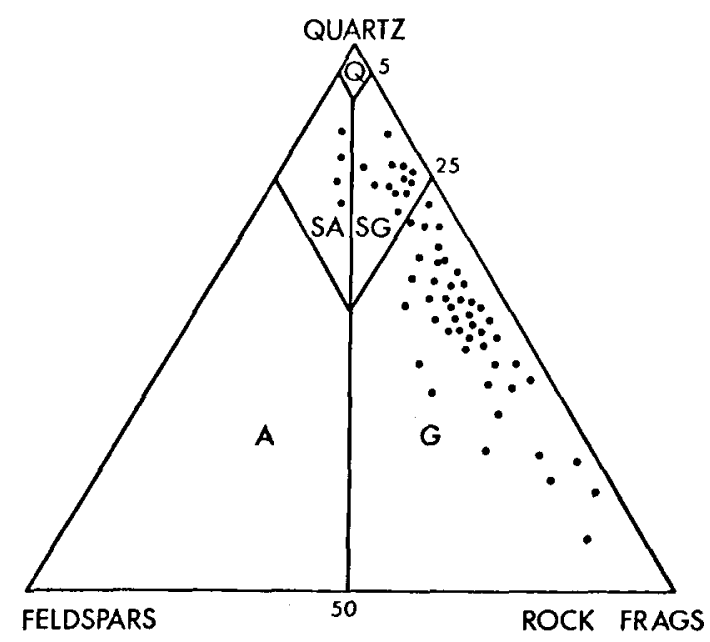

Fig.7. Petrographic classification of the sediments (after van Andel, 1958). Types are as follows: $Q=$ quartzose sand; $S G=$ subgraywacke; $G=$ graywacke; $S A=$ subarkose; and $A=$ arkose. The composition of the sediments is similar to that of material in local source areas (Hoare and Coonrad, 1961). 
subangular class in the Powers (1953) classification scheme, and the presence of a few subrounded samples is not regarded as significant because the accuracy of grain-roundness data is so low that results may be in error by a whole roundness class (Blatt et al., 1972).

\section{DISCUSSION}

\section{Textural and mineralogical relationships}

The mineralogy and texture of modern sediments is controlled by provenance and/or by selective sorting of different grain sizes (Folk, 1974). The influence of both of these factors is observed in Chagvan Bay deposits. A careful examination of the thin sections shows that no appreciable amount of physical or chemical alteration of the detrital fragments has occurred. Furthermore, because of the overall low degree of roundness of the samples, it is assumed that mechanical abrasion has not noticeably reduced the size of individual grains. At most it appears that mechanical abrasion has produced a disaggregation of some mineral grains from the lithic fragments. In addition, because the rate of diagenetic alteration is proportionate to the surface area of individual grains (Moore, 1968), the relatively low surface area to volume ratio of the lithic fragments minimizes this effect. The sediments are immature on a geological time scale, and physical and chemical factors have not yet altered the mineralogy or texture of individual grains with respect to provenance. The lithic fragment mineral components and internal grain texture are consistent with that of the outcrops in the Chagvan Bay area, i.e. the lithic fragments are dunites, sandstones and diorites.

Observed textural-mineralogical relationships are the result of provenance. Lithic fragments are predominant in the principal gravel mode $(-3$ to $-2 \phi)$ and quartz and feldspar grains are predominant in the fine sand mode $(2-3 \phi)$. Comparison studies of the trace-element geochemistry of the principal gravel and fine sand modes with detrital material from apparent source areas around Chagvan Bay have shown that these two modes are derived from the coastal bluffs and Bering Sea shelf, respectively (Owen, 1975; Owen and Moore, 1976). Identifiable grains in the coarse silt mode $(4-5 \phi)$ from the Kinegnak River are composed primarily of quartz.

Feldspar in well-sorted marine sands is primarily found in the 2-3 $\phi$ size fraction (Folk, 1974). Although Chagvan Bay sands are not well sorted, this textural-mineralogical relationship is still observed.

\section{Source areas and dispersal patterns}

The multimodal character of the bay deposits causes the dispersal patterns of sediments which comprise the principal grain-size modes to be obscured in the contour chart of mean grain size (Fig.5). For this reason, contour charts of the principal grain-size modes are shown (Figs.8-10) to provide a more informative representation of sediment dispersal patterns and grain-size 

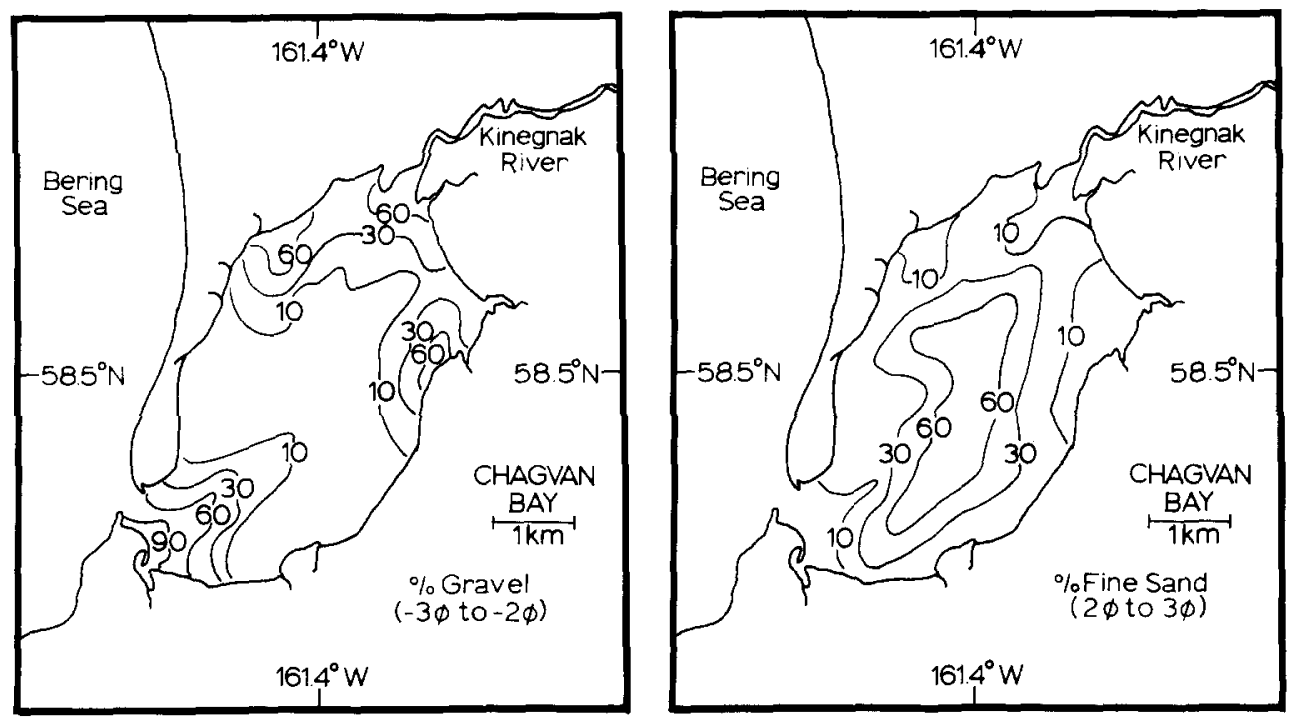

Fig.8. Distribution of gravel $(-3$ to $-2 \phi)$ in Chagvan Bay; principal mode occurs at about $-2.7 \phi$.

Fig.9. Distribution of fine sands $(2-3 \phi)$ in Chagvan Bay; principal mode occurs at about $2.5 \phi$.

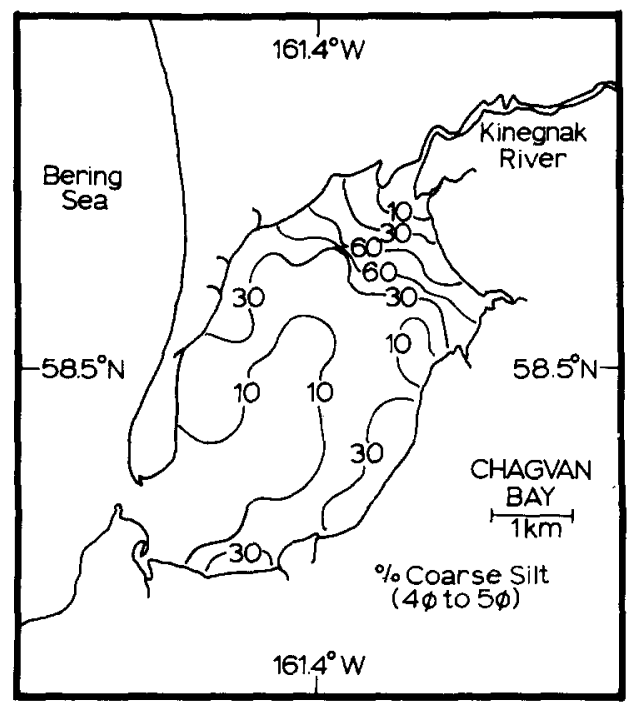

Fig.10. Distribution of coarse silts $(4-5 \phi)$ in Chagvan Bay; principal mode occurs at about $4.5 \phi$. 
variations. These dispersal patterns are strongly influenced by the tidal cycle and, particularly when the bay is drained during low tide, by river flow.

Sediments which comprise the principal gravel mode $(-3$ to $-2 \phi)$ decrease in concentration from the mouth of the bay to the head of the tidal channel in the southern half of the bay, and from coastal sources to the middle of the bay in the northern half of the bay (Fig.8). In each case it is assumed that the direction of decreasing percentage of material in this modal size, seen in Fig.9, is indicative of the transport direction (Booth, 1973; Slatt, 1975). A gravel bar at the southern tip of the bay mouth is the primary source of gravels found in the lower half of the bay. Gravels are eroded from this bar by waves and tidal currents and deposited within the tidal channel. However, this erosion cannot occur until the water level is sufficiently high to fill the tidal channel and cover its flanks. This situation exists only for about $6 \mathrm{hr}$, between the end of the flood-tide cycle and the beginning of the ebb-tide cycle, and this period does not correspond to the time of maximum current speed in the channel. Thus, it is likely that most of the eroded gravels are transported toward the head of the tidal channel during subsequent flood tides when the water is still confined to the channel and current speeds are relatively high. The decreasing concentration of gravels away from the bay mouth reflects the decreasing competence of the tidal current to transport this coarse material. During ebb tide the tidal current is subject to a funneling effect as it approaches the bay mouth. This effect restricts the outflow speed to 0.5$1.0 \mathrm{~m} \mathrm{sec}^{-1}$ until the cross-sectional area is reduced - about $2 \mathrm{~km}$ east of the bay mouth - where the speed increases to $2-3 \mathrm{~m} \mathrm{sec}^{-1}$. Thus, the ebb current is sufficient to affect seaward transport of gravels deposited at the mouth of the tidal channel, while gravels deposited in the head of the tidal channel are well within the zone of lower current speed and any transport of gravels from here back toward the bay mouth would be minor. Unfortunately, no currentvelocity data are available for Chagvan Bay for the period immediately following ice-melt, and further studies are needed to determine if the gravels deposited at the head of the tidal channel are transported seaward when the ebb current is augmented by river flood.

Gravel concentrations in excess of $10 \%$ form a continuous zone paralleling the shoreline in the northern half of the bay. The north-south limits of this zone are defined by the 10\% contour line (Fig.8), and correspond closely with the junction of glacial deposits and spit deposits on the western coast and of glacial deposits and bedrock outcrops on the eastern coast (Fig.2). The shoreline adjacent to this zone is being actively eroded (Owen, 1975) and the gravels here result from the deposition of wave-eroded material from the glacial bluffs.

Fine sands (2-3 $\phi)$ in Chagvan Bay (Fig.9) are derived from the adjacent nearshore shelf sediments in the Bering Sea and from beach deposits along the Bering Sea coast north of the bay, such as those which have produced the spit which forms the western boundary (Owen, 1975). Previously, an attempt was made to determine if the shelf and beach sediments do, in fact, represent a single or separate source areas by analyzing samples from both locations for 
a variety of physical and geochemical properties (Owen, 1975, 1976; Owen and Moore, 1976). These studies showed that there is no basis for considering these locations as separate source areas. The southward-flowing littoral current along the Bering Sea coast transports fine sands toward the bay mouth and from here they are transported into the bay by the tidal current. The dispersal pattern of fine sands in the bay is consistent with the observed counterclockwise path of the tidal current. Minimal concentrations of fine sand occur where current velocities are greatest, i.e., in the tidal channel and along the shoreline, while the highest concentrations occur in the deeper central portions of the bay. Because of the highly mobile character of fine sands, deposition in the central portions of the bay probably occurs during slack tide, when the tidal current velocity is at a minimum.

Coarse silts $(4-5 \phi)$ are transported into Chagvan Bay from the Kinegnak River and are primarily dispersed in the upper half of the bay (Fig.10). Silt deposition is favored when the bay is drained of sea water, which produces a river-dominant situation (cf. Wright, 1977) where the shallow depths immediately basinward of the river mouth enhance the effects of bed friction, causing more rapid deceleration and lateral expansion of the river flow. The silts are present as a minor facies at the river mouth owing to the abundance of gravels here (Fig.8). The highest concentrations of fluvial-derived silts occur beyond the zone of gravel deposition, about $1 \mathrm{~km}$ seaward of the river mouth, where they are mixed with fine sands and form the predominant facies in the central bay sediments.

Finally, linear tidal shoals characteristic of bidirectional sediment transport (Wright, 1977) are occasionally observed, which suggests that much of the deposited fine sands and silts are subsequently eroded and transported out of the bay during successive ebb tides.

In summary, the gravels generally result from wave erosion of the coastal bluffs or the gravel bar at the mouth of the bay, while the fine sands and coarse silts are primarily transported into the bay by tidal currents and fluvial currents, respectively. Tidal currents during successive ebb tides remove most or all of the newly deposited material and tend to maintain a balance between erosion and deposition. The stratigraphic implications of this system are discussed below.

Most of the sedimentary particles are being supplied to the depository at present, and the dispersal of the surficial sediments reflects the present configuration of distributor processes. Because of this age-process relationship, the sediments are classified as "neoteric" according to the McManus (1975) classification system.

\section{The distribution of benthic epifauna}

The observed system of waves and currents indicates that Chagvan Bay is a typical high-energy coastal environment during the ice-free months. An additional observation, which may be more indicative of the fine structure of energy levels in the bay, is the limited distribution of shell fragments and 
benthic epifauna. Collections of shell fragments, or death assemblages, generally occur in relatively low-energy areas, and these are found only in the lee of the spit that forms the western boundary of the bay. Similarly, live Cryptoma californica organisms, which are known to prefer a relatively stable substrate (K.G. Porter, pers. comm., 1976), also are limited to this quiescent zone, although other areas of the bay offer a compositionally similar substrate. Sediments deposited behind the spit are least disturbed by high-energy processes because it is outside the mainstream flow of the tidal current and because the morphology of the bay causes attenuation of waves reaching this zone. Thus, it is possible that the scouring action of waves and currents outside this zone renders the substrate unsuitable for habitation by the indigenous species. This argument is offered with the realization that many other factors can and undoubtedly do influence the distribution of benthic epifauna in an estuary. For example, the salinity and temperature structure, the incident light energy and the nutrient supply, among others, are also considered critical factors (Carriker, 1967). However, these factors are important to the establishment of separate biozones for benthic organisms only to the extent that they undergo significant lateral changes within the confines of the estuary and thereby create definitive microenvironments. But these factors probably remain fairly constant within Chagvan Bay because of the relatively small size of the embayment and the almost total predominance of tidal versus fluvial inputs. Consequently, lateral variations in scouring activity could be of paramount importance in controlling the distribution of benthic epifauna.

\section{Speculations on stratigraphic analogs}

One objective of this study was to consider how the depositional environment of a high-latitude embayment might be reflected in the stratigraphic record. Recent studies (Booth, 1973; Booth and Gorsline, 1974) have shown that a fruitful approach to this question is to examine the rate at which the sediments approach an equilibrium state following a perturbation which alters either or both the energy input and the sediment supply. An obvious perturbation of this type at Chagvan Bay is the effect produced by ice-cover, which is present about five months each year.

Following ice-melt there is a large input of sedimentary material resulting from spring runoff, after which the bay receives a fairly constant supply of detritus until it again becomes ice-covered. Throughout the ice-free period the sediments are dispersed and reworked by waves and currents. Thus, both sediment supply and the depositional energy level can be viewed as cyclic functions (Coleman and Wright, 1971) and these functions are controlled by ice-cover.

In attempting to estimate the equilibrium position of the bay, it is first noted that these cyclic functions are in phase. Therefore, it might be expected that the excess sediment supply during the ice-free period is matched by the highest energy levels, so that an equilibrium state is maintained. Booth and Gorsline (1974) have proposed two criteria which can be used to define 
such an equilibrium state: (1) the sediment surface must reflect the contemporary energy regime; and (2) there must be no net erosion or deposition, so that the sediment surface represents a hydraulically graded profile. The previous discussion of sediment-dispersal patterns demonstrates that the observed textural variations can be explained in terms of the existing energy regime. Furthermore, the mean grain size and sorting parameters show a hydraulically graded profile in going from coarse sediments in nearshore areas to finer sediments in the central portion of the bay. Since both of the criteria described above seem to be satisfied, it is concluded that there is an approximate balance in the flux of sedimentary material and that the bay is always at or near an equilibrium state. This balance between erosion and deposition should produce a diastem or unconformity in the stratigraphic record.

The above conclusion must be regarded as tentative, since net erosion or net deposition could be occurring at a rate too slow to be detected within the time-scale represented by the data of this study. It is worthwhile, then, also to consider these possibilities. If erosion were occurring at a relatively slow rate, this would also produce an unconformity as its stratigraphic equivalent, and a very thorough reconstruction of the paleohydraulics of the basin would be required to distinguish this situation from the equilibrium case. Similarly, net deposition at a slow rate would present an interesting challenge to the stratigrapher. Suppose, for example, that no major changes in the contemporary sediment characteristics occurred during lithification. Thus, a stratigraphic section would show a poorly sorted clastic aggregate, mostly subangular, with gravel-sized lithic fragments in a sandstone or muddy sandstone matrix. An important key to reconstructing this environment would be a knowledge of the lithology and proximity of the source area material to the depositional basin. Without this information, the deposit might appear to have characteristics of both low-energy and high-energy deposition. The poorly sorted, subangular texture and submature mineralogy would suggest rapid deposition without appreciable postdepositional reworking, while the presence of gravels (Folk, 1974) and absence of a clay matrix (Moore, 1968) could be regarded as manifestations of high-energy deposition.

These examples emphasize the somewhat unique range of variables which affect deposition in high-latitude embayments. The sediments furnished to Chagvan Bay are texturally discontinuous - they are, in fact, three distinct textural subpopulations: gravels from the coastal bluffs, fine sands from the Bering Sea and coarse silts from the Kinegnak River. Any mixture of these subpopulations will result in poorly sorted, multimodal sediments. The subpopulations will remain distinct only if they are selectively sorted by depositional processes. However, selective sorting occurs only within certain limits of the total energy spectrum. Energy levels which are above the maximum required for selective sorting will transport a mixture of textural subpopulations, while energy levels below the threshold limit will leave a mixture of these subpopulations unaffected. Another important factor here is the relatively small size of the depositional basin. It is probable that the dimensions of Chagvan Bay are too small to allow a complete separation of textural 
subpopulations, even when the energy input is at an optimum level for physical sorting. Finally, the subangular, immature appearance of the bay deposits is basically a consequence of the fact that the source area materials themselves are immature and, furthermore, that the detrital grains are transported relatively short distances prior to deposition and have had limited exposure to abrasive processes.

In summary, it is obvious that the speculations discussed above are merely illustrative, and that many other cases are possible. However, these considerations do show that considerable caution will have to be exercised when interpreting the stratigraphic analogs of high-latitude embayments, so that characteristics primarily related to provenance are not heavily weighed as indicators of depositional energy levels.

\section{CONCLUSIONS}

(1) Three major units of surficial sediments are recognized at Chagvan Bay: (1) coarse-grained lithic fragments $(-3$ to $-2 \phi)$ which are mostly dunites, diorites or sandstones; (2) fine sands $(2-3 \phi)$ composed of quartz and feldspar, and (3) coarse silts $(4-5 \phi)$ composed mostly of quartz. Field observations of sedimentary processes and comparisons of the bay sediments with local geology indicate that these three units are derived, respectively, from the coastal bluffs surrounding the bay, the adjacent nearshore and beach deposits along the Bering Sea coast north of the bay and the Kinegnak River.

(2) The texture and mineralogy of the bay deposits are primarily controlled by provenance. The surficial sediments are immature and no appreciable amount of physical or chemical alteration has occurred relative to their source area analogs.

(3) The major depositional processes are tidal currents, fluvial currents and waves. The interaction of these processes with the texturally diverse inputs from the source areas tends to produce a poorly sorted, multimodal sediment surface. Contour charts of the principal textural modes show that each major sediment unit is primarily associated with one dispersal process: the fine sands are transported into the bay by tidal currents, the coarse silts by fluvial currents and the gravels by wave erosion.

(4) Most of the sedimentary particles are being supplied to the depository at present, and the distribution of the surficial sediments reflects the present configuration of distributor processes. Because of this age-process relationship, the sediments are classified as "neoteric".

(5) Benthic epifauna are found only in relatively low-energy depositional areas, although similar biogeochemical environments are available in other parts of the bay. For this reason, it is postulated that the distribution of these organisms is influenced by the scouring activity of currents.

(6) The rates of sediment input and energy input are cyclic functions whose fluctuations are in phase and are controlled by ice-cover. Although the samples analyzed in this study were taken only about one month after icemelt, the sediment surface was found to reflect the contemporary energy 
regime and it formed a hydraulically graded profile. It is concluded from this that the bay is always at or near an equilibrium state. This situation should appear as a diastem or unconformity in the stratigraphic record. If, in fact, net erosion or net deposition were occurring, the stratigraphic analogs of these cases would be difficult to interpret. Net erosion would also produce an unconformity, and a thorough reconstruction of the paleohydraulics would be required to distinguish this situation from the equilibrium case. Net deposition could produce a stratigraphic record with characteristics typically associated with both high-energy and low-energy deposition. The key to resolving this anomalous situation would be an understanding of the lithology of source area materials, the spatial relationship between the source areas and the depositional basin, and the geometry of the basin.

\section{ACKNOWLEDGEMENTS}

This research was supported by a grant from the Sea Grant Program of the National Oceanic and Atmospheric Administration. All sample collecting and processing was done while both authors were associated with the Marine Research Laboratory, University of Wisconsin, Madison. We wish to express our thanks to Edward Olson for allowing us to base our operations at the Goodnews Bay Mining Company, and to James S. Booth, David K. Rea and Bruce $\mathrm{H}$. Wilkinson for critically reading the manuscript.

\section{REFERENCES}

Blatt, H., Middleton, G. and Murray, R., 1972. Origin of Sedimentary Rocks. PrenticeHall, Englewood Cliffs, N.J., 634 pp.

Booth, J.S., 1973. Textural changes as an indicator of sediment dispersion in the Northern Channel Island passages, California. J. Sediment. Petrol., 43: 238-250.

Booth, J.S. and Gorsline, D.S., 1974. Thoughts on new areas for research in shelf sediment transport studies. Mém. l'Inst. Géol. du Bassin d'Aquitaine, No. 7, 145-148.

Carriker, M.R., 1967. Ecology of estuarine benthic invertebrates: a perspective. In: G.H. Lauff (Editor), Estuaries. American Association for the Advancement of Science, Publ. No. 83 , pp.442-487.

Coakley, J.P. and Beal, G.S., 1972. SEDAN - A computer program for sediment particle size analysis. Canada Department of the Environment, Inland Waters Directorate, Rep. Ser. 20,33 pp.

Coleman, J.M. and Wright, L.D., 1971. Analysis of major river systems and their deltas, procedures and rationale with two examples. Louisiana State University Coastal Studies Institute Tech. Rep. 95.

Ferentinos, G.K., 1976. Sediment distribution and transport processes on the outer continental shelf of the Hebridean Sea. Mar. Geol., 20: 41-56.

Folk, R.L., 1974. Petrology of Sedimentary Rocks. Hemphill, Austin, Texas, 182 pp.

Hoare, J.M. and Coonrad, W.L., 1961. Geologic map of the Hagemeister Island Quadrangle, Alaska. U.S. Geol. Surv. Misc. Geol. Invest., Map I-321.

McManus, D.A., 1975. Modern versus relict sediment on the continental shelf. Geol. Soc. Am. Bull., 86: 1154-1160.

Mertie, J.B., Jr., 1940. The Goodnews platinum deposits, Alaska. U.S. Geol. Surv. Bull., 918, 97 pp. 
Mertie, J.B., Jr., 1969. Economic geology of the platinum metals. U.S. Geol. Surv., Prof. Pap. 630, $120 \mathrm{pp}$.

Mertie, J.B., Jr., 1976. Platinum deposits of the Goodnews Bay district, Alaska. U.S. Geol. Surv. Prof. Pap. 938, 42 pp.

Moore, J.R., 1968. Recent sedimentation in northern Cardigan Bay, Wales. Bull. Brit. Mus. (Nat. Hist.), 2(2): 22-131.

Moore, J.R., 1972. Exploitation of ocean mineral resources - perspectives and predictions. Proc. R. Soc. Edin., 12: 193-206.

Moore, J.R. and Welkie, C.J., 1976. Metal-bearing sediments of economic interest, coastal Bering Sea. Proc., Symposium on Sedimentation, Alaska Geological Society, K-1-K-17.

Owen, R.M., 1975. Sources and deposition of sediments at Chagvan Bay, Alaska. Ph.D. thesis, University of Wisconsin - Madison, $201 \mathrm{pp}$.

Owen, R.M., 1976. The selection and use of geochemical parameters as sediment tracers in high latitude coastal environments. Trans. Geophys. Union, 755.

Owen, R.M. and Moore, J.R., 1976. Sediment dispersal patterns as clues to placer-like platinum accumulation in and near Chagvan Bay, Alaska. Proc. 1976 Offshore Technology Conference, pp.307-318.

Porter, S.C., 1967. Glaciation of Chagvan Bay area, southwestern Alaska. Arctic, 20: 227-246.

Powers, M.C., 1953. A new roundness scale for sedimentary particles. J. Sediment. Petrol., 23: $117-119$.

Slatt, R.M., 1975. Dispersal and geochemistry of surface sediments in Halls Bay, northcentral Newfoundland: application to mineral exploration. Can. J. Earth Sci., 12(8): 1346-1361.

Spencer, D.W., 1963. The interpretation of grain size distribution curves of clastic sediments. J. Sediment. Petrol., 33(1): 180-190.

van Andel, T.H., 1958. Origin and classification of Cretaceous, Paleocene, and Eocene sandstones of western Venezuela. Bull. Am. Assoc. Pet. Geol., 42: 734-763.

von Arx, W.S., 1967. An Introduction to Physical Oceanography. Addison-Wesley, Reading, Mass., 422 pp.

Wentworth, C.K., 1922. A scale of grade and class terms for clastic sediments. J. Geol., 30: $377-392$.

Wright, L.D., 1977. Sediment transport and deposition at river mouths: a synthesis. Geol. Soc. Am. Bull., 88: 857-868. 